\title{
“Commentary to "How International Are the Top Ten International Journals of Criminology and Criminal Justice?" by Ken Pease"
}

\author{
Ken Pease ${ }^{1}$ \\ Published online: 10 December 2019 \\ (C) Springer Nature B.V. 2019
}

\section{Criminology and the Tower of Babel}

The biblical story of the Tower of Babel (Genesis 11:1-9) seeks to account for the existence of diverse human languages. Somewhere along the line, the English seem to have cheated. Those aspiring to an academic career born with English as their first language enjoy a very substantial advantage over equally or more talented people with a different linguistic heritage. English is the lingua franca of science discourse. The primacy of English lies at the heart of the problems which the Faraldo-Cabana paper (hereinafter F-C) identifies. That paper samples journals which claim to be international and shows how far they typically fall short of justifying that claim. F-C points out that national borders are of little importance to many of the most pressing crime problems. It is crucial that an international approach be fostered. Urgent international crime problems such as cyber warfare, trafficking of people, and trade in endangered species products cannot be confronted with scholarship based on intra-national analyses. Accordingly, journals should be truly international or cease to make the claim that they are. F-C and colleagues set out three basic attributes which an international journal should possess:

1) An editorial staff composed of highly respected scholars from different countries and linguistic communities.

2) A policy of publishing high-level, internationally refereed scientific articles written by a significant percentage of authors from different countries and linguistic communities.

3) A strong capability to attract international contributions, in particular, through coauthorship involving authors from different countries.

This commentary seeks to make three points. First, while there are aspects of the method adopted by F-C might be contested, the big picture portrayed is accurate, indeed familiar to anyone minded to see it. Second, some of the real and substantial obstacles to the realization of the vision of a well-founded global discipline studying crime and justice will be identified.

Ken Pease

kengpease@gmail.com

1 University of Derby, Kedleston Road, Derby DE22 1GB, UK 
Third, taking the primacy of English as lying at the core of the problem, a radical suggestion about how journals could operate will be made. This should be taken as a challenge rather than a prescription.

\section{Quibbles and Why They Do Not Matter}

F-C stridently identifies the elephant in the room as regards scholarship about crime and justice. The discipline is US-centric (and to a lesser extent centred on other Anglophone nations). This may readily discerned from citation patterns and from attendance patterns between and within international conferences. One may quibble about F-C's mode of selection of journals as internationally oriented, and some details of method. These details carry over into interpretation of results. If (for example) a journal gets into the sample studied, that probably means it wants to be international in coverage. It would have been interesting to look at trends in editorial board membership. As it stands, journals which have embarked, however imperfectly, on the road to internationalism will be castigated, while those which have not (and thereby do not make it into the sample) go on their myopic way uncensured. Trends in the composition of editorial board membership of those journals could then be read, not as reflecting a culpable exclusion of non-Anglosphere work but as reflecting at least movement in the international direction. Of course, trends showing no movement towards internationalism in journals badging themselves as international would be a cause for concern.

My only other qualifier in admiration for F-C lies in the conflation of UK and USA work as 'Anglo-American'. This will certainly be seen as special pleasing by the UK based writer but here goes anyway. US criminology is more inward looking than is the case elsewhere in the 'Anglosphere' (a term redolent of colonial history). Consider, for example, US work which explored the crime drop, which considered domestic US trends as determinants long before recognising the near-global nature of the drop (see Tonry 2014). European scholars were much quicker to see the pattern (and hence the candidate explanations) as international (Farrell et al. 2008).

Whatever minor criticisms one cares to make of the F-C paper, the picture it paints of a discipline failing to access global consciousness befitting global problems is accurate and timely.

\section{Here Be Dragons}

To reach a point where academic literature is commensurate with the problems it seeks to address, we need to be clear about the obstacles which will be encountered along the way. The writer's friend and most frequent collaborator of recent years has been Professor Dainis Ignatans, who is a Latvian. Recognition of the problems has been sharpened by that collaboration and I am grateful to Dainis for many relevant discussions, especially the consequences of the cultural and linguistic divisions within Latvia. We do need to consider intra-national linguistic variation. Dainis and I do not agree on everything, so he should not be assumed to share all the views expressed below. There follows some of the obstacles to be overcome.

- There are 473 universities offering first degrees in criminology in the USA. There appear to be 13 in Poland. The volume of US research seeking a publication outlet is thus massive 
by comparison with the volume of research coming out of countries like Poland. The volume of US research is possibly greater than that coming from most other nations combined. F-C describes journal editors as 'gatekeepers'. This is partially true but they only become relevant when people knock at the gate. The editorial process starts with submission of manuscripts. How is an editor to behave when most submissions come from people affiliated to US institutions? Is she to apply a double standard for acceptance? Assuming the proportion of acceptable manuscripts from US sources is similar to that from elsewhere, does she live with the consequence that most of her journal's content will report US work?

- The economics of publication favours countries with high criminologist numbers. It also favours rich countries, particularly when open-access publication requires a fee to be paid by an author or the institution to which he or she is affiliated.

- The language of academic criminology is predominantly English. My experience as a reviewer has been that it takes much longer adequately to review work, however fine, by scholars whose first language is not English, because it involves the dual tasks of fully understanding the content and suggesting style changes to ensure that the intended message is conveyed. Lest I be misunderstood, this has nothing to do with the quality of the research, rather it is a wholly undesirable consequence of the primacy of English as the vehicle of social science publication. The writer has French as a second language but struggles to write with complete clarity and nuanced expression in that language.

- Victimisation surveys and other important datasets are readily available in North America and Western Europe far more than is the case elsewhere.

- Sociologists write for sociology journals, lawyers for law journals, psychologists for psychology journals. Criminology is a hybrid discipline. The disciplines which contribute to it vary by country. Thus, journal submissions across national borders are often working across two barriers, country and discipline. I have recently reviewed a number of papers from China and South Korea where the emphasis is on engineering solutions to crime. It is challenging to reviewers from a country with a different discipline base. This is exacerbated by the primacy of frequentist statistics in US research, which sometimes seems a matter of doctrine rather than reasoned epistemological choice.

- Different scholarly publications legitimately have different audiences. I am currently working on the topic of long-term police suspensions from duty ending with exculpation. This is an important topic in the UK context. It is probably an important topic elsewhere, but the relevant access to data is difficult enough within one police force, let alone generally in the UK, still less across national boundaries. The problem here is how to frame the work so that even when feasibility means that data come from one country, international replication is invited.

\section{A Little Self-Flagellation and a Radical Suggestion}

Let me get the self-flagellation out of the way first. I know I am on some editorial boards but do not know which. This is an appalling admission to make and I here resolve to find out and contribute to journal policy.

The radical suggestion takes language to be the central obstacle to internationalism in journal production. Let me introduce the skeuomorph. This is the phenomenon whereby design features persist when technology makes them unnecessary. The gambling machines 
variously known as fruit machines or one armed bandits have (as the name suggests) a lever which is pulled to activate a play. With computerized operation, the lever is entirely unnecessary. It is a skeuomorph. Digital cameras feature a sound which mimics that of a mechanically activated shutter of earlier cameras. Electric cars feature unnecessary radiator grilles. Examples of skeuomorphs are everywhere once one looks for them. I think current modes of journal publication are skeuomorphic if one wishes to foster an international mindset.

We live in a world where Google Translate is available and increasingly impressive. How about a journal of global criminology in which an author submits content in his or her preferred language? Two (say) reviewers from linguistic communities different from each other and from that of the content author convert the content into their own preferred language. The journal editor (as now) reconciles suggestions for revision made by the reviewers and forwards them to the author. At every stage (author, reviewer, editor) the user's preferred language would be used. The journal would appear online in a subscriber's nominated preferred language.

If I continue in this vein, I will certainly become skeuomorphic myself so I will desist. Information scientists can be relied upon to devise a system which combines assurance that a reader finds what she is looking for together with an elements of serendipity, so that novel associations (what used to be called bisociation) are encouraged.

The reader will (and probably should) ridicule the specifics of the above suggestion. The point is this. The apparatus of journal publication that F-C seeks to tweak should be fundamentally rethought in the light of what is now possible. If we were starting from scratch, how would we replace the Tower of Babel?

\section{References}

Farrell G., Tilley N., Tseloni A. and Mailley J. (2008). British Society of Criminology Newsletter. no. 62, winter Tonry, M. (2014). Why crime rates are falling throughout the Western world. Crime and Justice, 43(1), 1-63.

Publisher's Note Springer Nature remains neutral with regard to jurisdictional claims in published maps and institutional affiliations. 